СОВРЕМЕННЫЕ ЭТНОДЕМОГРАФИЧЕСКИЕ ПРОЦЕССЫ

\title{
Л.A. Попова*
}

\section{Тенденции разводимости населения в Республике Коми в XX веке и начале XXI века**}

\begin{abstract}
Рассмотрены тенденции разводимости населения Республики Коми на протяжении последних 100 лет. Выделены факторы, определявшие уровень разводимости в разные периоды времени: трансформация брачно-семейных отношений после революции, нормативно-правовые акты в сфере семьи и брака, отношение населения к разводам, внешние обстоятельства (Великая Отечественная война, изменения 8 нравственно-психологическом состоянии российского общества в конце 1980-х г2. - начале 1990-х г2., сочиально-экономический кризис 1990-х г2.). Наиболее подробно проанализировань 1990-е - начало 2000-х г2., располагающие хорошей статистической информащионной базой.
\end{abstract}

Ключевые слова: стабильность семейной жизни, разводимость, брачно-семейное законодательство, Республика Коми

\section{L.A. Popova \\ Trends of population divorce in the Komi Republic in the $X X$ century and the beginning of the XXI century}

The article examines the trends of divorce rates in the Komi Republic over the past 100 years. The author identifies the factors that determined the level of divorce in different periods: the transformation of marital and family relations after the revolution, legal acts in the field of family and marriage, the attitude of the population to divorce, external circumstances (the Great Patriotic war, changes in the moral and psychological state of Russian society in the late 1980s-early 1990s, the socio-economic crisis of the 1990s). The most detailed analysis is made of the 1990s and early 2000s, which have a good statistical information base.

Key words: stability of family life, divorce rate, marriage and family legislation, Komi Republic

В демографических исследованиях основной фокус внимания сосредоточен на рождаемости, смертности и миграции населения. В то же время движение семьи включается в понятие воспроизводства населения в широком смысле слова, соответственно, изучение закономерностей развития брачно-семейных отношений также является частью демографического анализа. Кроме того, все демографические процессы взаимосвязаны и взаимообусловлены. Особенности развития семейной структуры населения оказывают влияние на показатели рождаемости, уровень смертности, степень миграционной подвижности населения. Ранее нами были рассмотрены тенденции брачности населения Республики Коми в 1920-1990-е гг. и факторы, их обуславливающие [1]. Данная статья посвящена тенденциям разводимости населения республики на протяжении советского периода, в 1990-е гг. и в начале нового столетия.

\footnotetext{
* Попова Лариса Алексеевна (Сыктывкар) - доктор экономических наук, доцент, заместитель директора по научной работе Института социально-экономических и энергетических проблем Севера Коми научного центра Уральского отделения Российской академии наук Федерального государственного бюджетного учреждения науки Федерального исследовательского центра «Коми научный центр Уральского отделения Российской академии наук» (ИСЭ и ЭПС ФИЦ Коми НЦ УрО РАН), Сыктывкар, Республика Коми, Российская Федерация. popova@iespn.komisc.ru

** Статья подготовлена в рамках темы НИР «Население северных территорий России: история формирования и перспективы развития» (№ гос. регистрации АААА-А19-119012190103-0).
} 
Движение семьи, ее демографическое развитие характеризуется, прежде всего, рождением детей, количество которых определяется репродуктивными установками супругов и степенью их реализации, а также длительностью супружеской жизни, которая во многом зависит от стабильности брака. Практически на протяжении всей советской истории в стране происходило усиление факторов, так или иначе способствующих повышению уровня разводимости: отделение брака от церкви, а церкви от государства, массовая секуляризация общественного сознания, уравнение женщин в правах с мужчинами, повышение уровня образования и широкое вовлечение женщин в общественное производство, обусловившие их экономическую независимость, развитие социального обеспечения, общее повышение уровня жизни населения, урбанизация, рост обеспеченности населения жильем и пр.

Особенно заметный рост показателей разводимости наблюдался в первые годы Советской власти, характеризовавшиеся становлением новых, революционных, брачно-семейных отношений. Подписание в декабре 1917 г. декрета ВЦИК и СНК РСФСР «О расторжении брака» [2] и принятие в 1918 г. «Кодекса законов РСФСР об актах гражданского состояния, брачном, семейном и опекунском праве» [3] в корне изменило в стране отношение к вопросу о расторжении брака. Сосредоточив свое внимание на признании брака, зарегистрированного в государственных органах, на равенстве всех детей, Семейный кодекс 2018 г. уделял минимум внимания регулированию иных семейных отношений, а то и вовсе их игнорировал [4, с. 75]. В результате, если в дореволюционной России разводом заканчивался лишь один брак из 225, то в 1926 г. - уже каждый седьмой [5, с. 52].

Введенный в действие с 1 января 1927 г. новый, второй по счету, «Кодекс законов о браке, семье и опеке РСФСР» [6] придал юридическое значение гражданскому сожительству - фактическим брачным отношениям, не зарегистрированным в органах ЗАГС, которые отныне приравнивались к юридически оформленному браку. Необязательность даже крайне легкой в соответствии с новым Кодексом, практически протокольной процедуры юридической регистрации брака не предусматривала и обязательности юридического оформления столь же легкой процедуры развода, который мог состояться как по обоюдному согласию супругов, так и по одностороннему желанию кого-нибудь из них.

Однако жизнь очень скоро показала, что новые брачно-семейные отношения не во всем оказались позитивными. Необязательность регистрации брака и чрезвычайная легкость развода в 1920-1930 гг. довольно часто имели следствием безответственность в вопросах семейной жизни, особенно у мужчин. Первым шагом в начавшейся политике последовательного отказа от свободы брака явилось Постановление ЦИК СССР № 65 и СНК СССР № 1134 от 27.06.1936 г. «О запрещении абортов, увеличении материальной помощи роженицам, установлении государственной помощи многосемейным, расширении сети родильных домов, детских яслей и детских садов, усилении уголовного наказания за неплатеж алиментов и о некоторых изменениях в законодательстве о разводе» [7], которым в целях борьбы с легкомысленным отношением к семье и семейным обязанностям был установлен личный вызов в органы ЗАГС обоих разводящихся супругов с обязательной отметкой о разводе в их паспорте. Кроме того, была повышена оплата регистрации разводов: первый развод - 50 руб., второй - 150 руб., каждый последующий - 300 руб. [4, с. 76].

Скудные, собранные по крупицам данные по Республике Коми за довоенный период позволяют зафиксировать достаточно заметное снижение уровня разводимости: с 2,2 разводов на 1000 человек населения в 1930 г. до 0,8\% в 1940 г. (табл.1). В дальнейшем, в результате значительных потерь населения в ходе Великой Отечественной войны, которые привели к резкой диспропорции полов, ситуация с разводимостью сновао ухудшилась. К концу войны стало достаточно очевидно, что в условиях существенного дисбаланса на брачном рынке мужчины легко могут по несколько раз вступать в брак. Тем более что для этого не обязательно и регистрироваться, а в случае регистрации очень легко развестись. Это ставило под угрозу устои советской семьи [8]. Призванный поднять авторитет брака как основы семьи Указ Президиума Верховного Совета СССР от 8.07.1944 г. «Об увеличении государственной помощи беременным женщинам, многодетным и одиноким матерям, усилении охраны материнства и детства, об установлении высшей степени отличия - звания «Матьгероиня» и учреждении ордена «Материнская слава» и медали «Медаль материнства» [9] не только предусматривал обязательную регистрацию брака, но и существенно усложнил порядок его расторжения.

Согласно Указу 1944 г., брак можно было расторгнуть только через суд. Для подачи заявления на развод требовалось выполнить ряд условий: указать мотивы развода, вызвать в суд другого супруга для ознакомления с заявлением, опубликовать в местной газете объявление о расторжении брака и др. Расторжение брака судом имело двухступенчатую процедуру: сначала заявление рассматривал народный суд, которому надлежало выявить истинные мотивы развода и принять меры к примирению супругов, явка которых на судебное заседание считалась обязательной. Если примирения супругов в народном суде не происходило, истец обращался с заявлением о разводе в вышестоящий суд, который и принимал решение по существу вопроса. Если до этого Указа государственные органы лишь регистрировали факт развода, то теперь именно суд решал вопрос о наличии 
причин для прекращения брака. При этом расторжение брака, даже если фактически семья уже перестала существовать, рассматривалось в обществе как безнравственное, осуждаемое поведение со всеми вытекающими негативными последствиями: публичным осуждением, исключением из партии и пр. [4, с. 77].

Таблицุа 1

\section{Динамика общего коэффициента разводимости населения Республики Коми, разводов на 1000 человек населения}

\begin{tabular}{|c|c|c|c|c|c|c|c|}
\hline Год & $\begin{array}{c}\text { Все } \\
\text { население }\end{array}$ & $\begin{array}{l}\text { Городское } \\
\text { население }\end{array}$ & $\begin{array}{c}\text { Сельское } \\
\text { население }\end{array}$ & Год & $\begin{array}{c}\text { Bce } \\
\text { население }\end{array}$ & $\begin{array}{l}\text { Городское } \\
\text { население }\end{array}$ & $\begin{array}{c}\text { Сельское } \\
\text { население }\end{array}$ \\
\hline 1920 & 0,5 & $\ldots$ & $\ldots$ & 1989 & 4,5 & 5,3 & 2,3 \\
\hline$\ldots$ & & & & 1990 & 4,2 & 4,8 & 2,0 \\
\hline 1930 & 2,2 & $\ldots$ & $\ldots$ & 1991 & 4,9 & 5,7 & 2,3 \\
\hline$\ldots$ & & & & 1992 & 5,4 & 6,4 & 2,5 \\
\hline 1939 & 0,9 & $\ldots$ & $\ldots$ & 1993 & 5,5 & 6,3 & 2,9 \\
\hline 1940 & 0,8 & $\ldots$ & $\ldots$ & 1994 & 5,9 & 6,9 & 3,1 \\
\hline$\ldots$ & & & & 1995 & 5,7 & 6,5 & 3,2 \\
\hline 1945 & & & & 1996 & 4,3 & 5,0 & 2,1 \\
\hline$\ldots$ & & & & 1997 & 3,9 & 4,5 & 2,0 \\
\hline 1950 & 0,4 & 0,5 & 0,3 & 1998 & 4,0 & 4,7 & 2,0 \\
\hline$\ldots$ & & & & 1999 & 3,8 & 4,6 & 1,6 \\
\hline 1955 & 0,8 & $\ldots$ & $\ldots$ & 2000 & 4,8 & 5,6 & 2,6 \\
\hline$\ldots$ & & & & 2001 & 5,9 & 6,9 & 2,8 \\
\hline 1960 & 1,6 & 2,2 & 0,5 & 2002 & 6,1 & 7,0 & 3,4 \\
\hline$\ldots$ & & & & 2003 & 5,5 & 6,3 & 3,0 \\
\hline 1965 & 2,0 & $\ldots$ & $\ldots$ & 2004 & 4,9 & 5,7 & 2,5 \\
\hline$\ldots$ & & & & 2005 & 4,6 & 5,2 & 2,1 \\
\hline 1970 & 3,7 & 4,2 & 1,5 & 2006 & 4,9 & $\ldots$ & $\ldots$ \\
\hline$\ldots$ & & & & 2007 & 5,3 & $\ldots$ & $\ldots$ \\
\hline 1975 & 4,0 & $\ldots$ & $\ldots$ & 2008 & 5,7 & $\ldots$ & $\ldots$ \\
\hline$\ldots$ & & & & 2009 & 5,7 & $\ldots$ & $\ldots$ \\
\hline 1980 & 4,8 & 5,7 & 2,4 & 2010 & 5,1 & $\ldots$ & $\ldots$ \\
\hline 1981 & 4,6 & 5,4 & 2,4 & 2011 & 5,4 & $\ldots$ & $\ldots$ \\
\hline 1982 & 4,3 & 5,1 & 2,4 & 2012 & 5,3 & $\ldots$ & $\ldots$ \\
\hline 1983 & 4,4 & 5,1 & 2,3 & 2013 & 5,6 & $\ldots$ & $\ldots$ \\
\hline 1984 & 4,4 & 5,3 & 2,1 & 2014 & 5,6 & $\ldots$ & $\ldots$ \\
\hline 1985 & 4,4 & 5,0 & 2,4 & 2015 & 4,8 & $\ldots$ & $\ldots$ \\
\hline 1986 & 4,4 & 5,0 & 2,5 & 2016 & 4,8 & $\ldots$ & $\ldots$ \\
\hline 1987 & 4,4 & 5,0 & 2,5 & 2017 & 5,0 & $\ldots$ & $\ldots$ \\
\hline 1988 & 4,3 & 4,9 & 2,3 & 2018 & 4,6 & $\ldots$ & $\ldots$ \\
\hline
\end{tabular}

Источники: Статистические сборники Комистата; 10, с. 107; 11, с. 24; 12, с. 109.

...- Нет данных.

Указ 1944 г. имел следствием значительное сокращение числа разводов в первый послевоенный период, однако длилось оно недолго. В Республике Коми уже к середине 1950-х гг. общий коэффициент разводимости вернулся к предвоенному уровню. Правда, с учетом существеннейшего сокращения к этому времени количества фактических браков, которые Указом были поставлены «вне закона», и послевоенного компенсационного роста официальной брачности, в Республике Коми значительно усиленного массовым миграционным притоком населения в возрастах максимальной брачности, одинаковый уровень общего коэффициента разводимости вовсе не свидетельствует о полной схожести ситуации со стабильностью семьи, сложившейся в 1950-е гг., с ситуацией, характерной для 1930-х гг. Но, с другой стороны, неизвестно и то, сколько браков распадалось после войны фактически - без формального оформления развода, и сколько внебрачных детей выросли безотцовщиной в результате этого усложнения процедуры развода.

К тому же уровень разводимости продолжал расти и в дальнейшем. К 1965 г., в условиях неизменности в стране брачно-семейного законодательства, разводом вновь стало заканчиваться каждое шестое супружество - столько же, сколько в 1920-1930-е гг., при несравненно бо́льшей в то время легкости развода [13, с. 59]. В Республике Коми, которая, по крайней мере, с начала 1960-х гг,, отличается более высокими показателями разводимости по сравнению со средними по России (табл. 2), общий коэффициент разводимости в 1965 г. 
практически достиг уровня 1930 г., характеризовавшегося и достаточно близкими с 1965 г. показателями официальной брачности населения. Жизнь все больше показывала несостоятельность тех жестких мер, с помощью которых в течение 20 лет в стране пытались укрепить семью.

Таблица 2

Динамика общего коэффициента разводимости населения Российской Федерации и Республики Коми, разводов на 1000 человек населения

\begin{tabular}{|c|c|c|c|c|c|}
\hline Год & $\begin{array}{c}\text { Российская } \\
\text { Федерация }\end{array}$ & $\begin{array}{c}\text { Республика } \\
\text { Коми }\end{array}$ & Год & $\begin{array}{c}\text { Российская } \\
\text { Федерация }\end{array}$ & $\begin{array}{c}\text { Республика } \\
\text { Коми }\end{array}$ \\
\hline 1960 & 1,5 & 1,6 & 1998 & 3,4 & 4,0 \\
\hline$\ldots$ & & & 1999 & 3,7 & 4,8 \\
\hline 1965 & 1,8 & 2,0 & 2000 & 4,3 & 5,9 \\
\hline$\ldots$ & & & 2001 & 5,3 & 6,1 \\
\hline 1970 & 3,0 & 3,7 & 2002 & 6,0 & 5,5 \\
\hline$\ldots$ & & & 2003 & 5,5 & 4,9 \\
\hline 1975 & 3,6 & 4,0 & 2004 & 4,4 & 4,6 \\
\hline$\ldots$ & & & 2005 & 4,2 & 5,9 \\
\hline 1980 & 4,2 & 4,8 & 2006 & 4,5 & 5,3 \\
\hline$\ldots$ & & & 2007 & 4,8 & 5,7 \\
\hline 1985 & 4,0 & 4,4 & 2008 & 4,9 & 5,1 \\
\hline$\ldots$ & & & 2009 & 4,9 & 5,4 \\
\hline 1989 & 3,9 & 4,5 & 2010 & 4,5 & 5,3 \\
\hline 1990 & 3,8 & 4,2 & 2011 & 4,7 & 5,6 \\
\hline 1991 & 4,0 & 4,9 & 2012 & 4,5 & 5,6 \\
\hline 1992 & 4,3 & 5,4 & 2013 & 4,7 & 4,8 \\
\hline 1993 & 4,5 & 5,5 & 2014 & 4,7 & 4,8 \\
\hline 1994 & 4,6 & 5,9 & 2015 & 4,2 & 5,0 \\
\hline 1995 & 4,5 & 5,7 & 2016 & 4,1 & 4,6 \\
\hline 1996 & 3,8 & 4,3 & 2017 & 4,2 & 4,0 \\
\hline 1997 & 3,8 & 3,9 & 2018 & & \\
\hline
\end{tabular}

* Источники: 14, с. $119 ; 15 ; 16$, с. $24 ; 17$.

... - Нет данных.

10 декабря 1965 г. был издан Указ Президиума Верховного Совета СССР «О некоторых изменениях порядка рассмотрения в судах дел о расторжении брака» [18], который заметно упростил процедуру расторжения брака. Развод опять полностью перешел в компетенцию судов первой инстанции: районных (городских) народных судов. Были отменены объявления в газетах о предстоящих бракоразводных процессах. В первый после этого год в стране произошло скачкообразное повышение уровня разводимости, явившееся результатом того, что сразу после упрощения процедуры в массовом порядке были оформлены разводы, которые фактически давно состоялись. Но уже в 1967 г. темпы роста уровня разводимости значительно сократились, а новое упрощение бракоразводной процедуры в результате принятия в 1968 г. нового брачно-семейного кодекса [19] на числе разводов и вовсе никак не отразилось [13]. Разводимость в стране продолжала расти, следуя своим закономерностям, поскольку общественное мнение все более терпимо относилось к факту расторжения брака.

В 1980-е гг. рост уровня разводимости перешел в стабилизацию и даже снижение. А начало 1990-х гг. в Республике Коми, как и по России в целом, ознаменовалось новым повышением ее уровня (рис. 1). Рост был не очень продолжительным - до 1994 г. Однако он происходил в условиях существенного снижения уровня брачности населения и, соответственно, свидетельствует о значительном нарастании в эти годы нестабильности брачно-семейных отношений.

Широкое распространение добрачных и внебрачных половых связей, значительное повышение уровня требований супругов друг к другу в интимной сфере в результате хлынувших во второй половине 1980-х годов из всех СМИ потоков сексуальной информации гедонистического направления - при недостатке общей и контрацептивной культуры населения во многом способствовали семейной дезорганизации. Определенную роль сыграли и социальные последствия начавшихся экономических реформ, приведшие к обнищанию значительных слоев населения и сильнейшей поляризации общества на бедных и богатых: исследования развития семьи в условиях заметного социального расслоения показывают, что семьи, сосредоточенные на противоположных полюсах, гораздо сильнее, чем средние по уровню жизни, подвержены влиянию дестабилизирующих факторов [20]. 


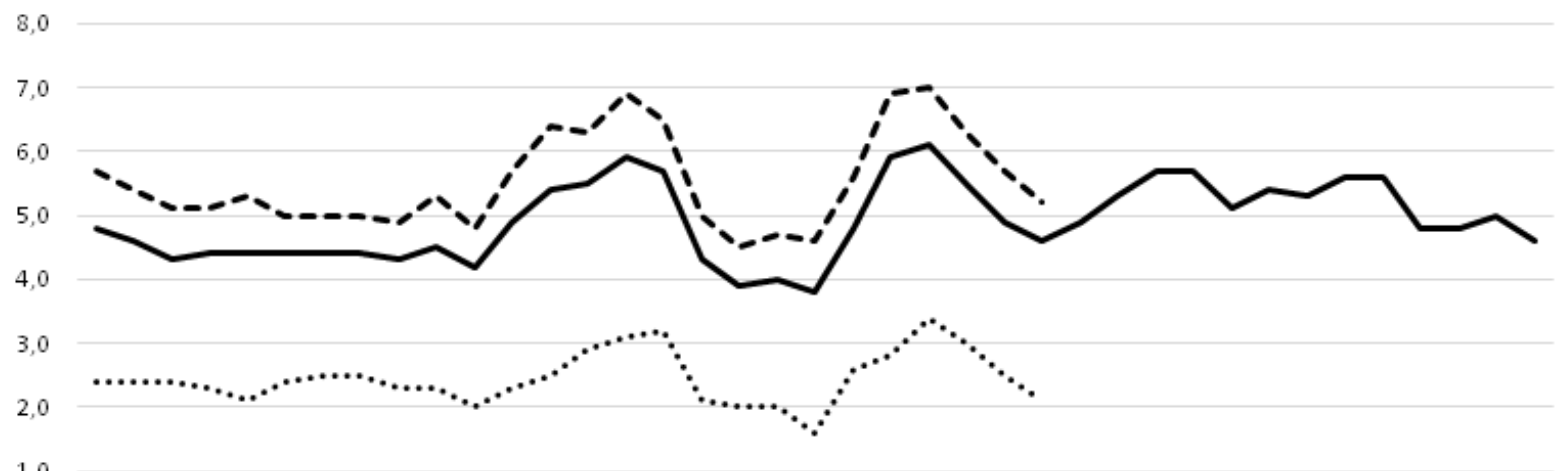

1,0

0,0

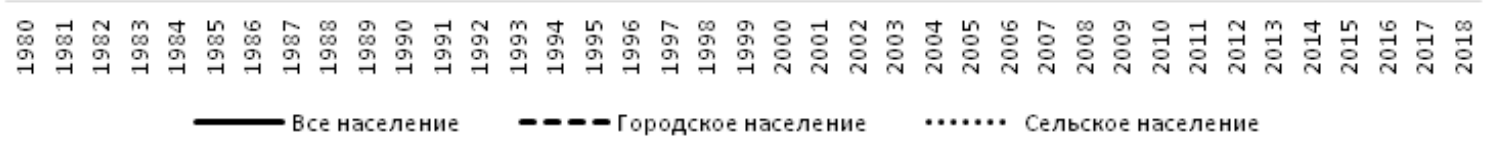

Рис. 1. Динамика общего коэффициента разводимости

в Республике Коми в 1980-2018 г2., разводов на 1000 человек населения.

Здесь следует отметить, что период социально-экономического и демографического кризиса в России 1990-е гг. и самое начало 2000-х гг. - оказался наиболее информативным в плане доступности детальной статистической информации о развитии брачно-семейных отношений. По разводимости населения органами статистики в этот период разрабатывались и публиковались самые разнообразные показатели: уровень по полу и возрасту разводящихся, по очередности и продолжительности брака, по наличию и количеству детей в семье и пр. - которые давали возможность производить полноценный анализ не только динамики уровня, но и закономерностей развития процесса. А после 2004 г. в демографических ежегодниках Республики Коми не публикуется даже информация об уровне разводимости отдельно по городской и сельской местности. Лишь за 2005 г. этот показатель удалось найти в экспресс-информации «Естественное движение населения Республики Коми за 2005 год» [11, с. 25]. В последующие годы показателей по городу и селу нет также и в этих бюллетенях. А в демографических ежегодниках остался только уровень разводимости по всему населению республики и абсолютно неинформативные для исследователей ввиду незначительности статистических совокупностей показатели разводимости по муниципальным образованиям и не представляющие научного интереса числа разводов по месяцам года.

Как видно по имеющимся данным (табл. 1, рис. 1), общий коэффициент разводимости городского населения Республики Коми в 2-2,5 раза выше, чем в сельской местности. В отдельные годы - даже в три. И причина здесь не только в более старой возрастной структуре сельского населения: как известно, развод - «привилегия» молодых. Вероятности развестись к определенному возрасту, рассчитываемые по принципу суммарного коэффициента - суммированием половозрастных коэффициентов разводимости, в городской местности также значительно превосходят аналогичные показатели в сельской, особенно для мужчин. Так, при уровне показателей разводимости, характерном для 1994 г. - года максимального для 1990-х гг. уровня официальной разводимости - вероятность развестись к 50 годам в Республике Коми имели 59,3\% мужчин и $71,9 \%$ женщин. При этом в городской местности 68,0 \% мужчин и 79,4 \% женщин, в сельской $-31,9$ \% мужчин и $44,4 \%$ женщин. Причем у сельского населения вероятность развестись до 50 лет немножко увеличилась еще и в 1995 г. - до $32,7 \%$ у мужчин и $45,0 \%$ у женщин.

А в целом по населению республики в 1995 г. рост показателей разводимости перешел в стабилизацию, а затем довольно заметное снижение, продолжавшееся в течение 5 лет. Отметим, что по времени эта благоприятная тенденция совпала с подготовкой и принятием в конце 1995 г. нового Семейного кодекса Российской Федерации [21], когда вопросы, касающиеся проблем развития семьи, имели широкое общественное звучание. В результате этого снижения к концу 1990-х гг. в республике были достигнуты уровни начала 1970-х.

Однако следует учесть, что 1990-е и 1970-е гг. принципиально различаются по брачной ситуации. В 1970-е гг. в республике наблюдался рост показателей официальной брачности, в то время как 1990-е ознаменовались расширением распространения фактической браков, а официальная брачность оказалась на уровне 1920-1930-х гг. В 1999 г., когда в Республике Коми наблюдался минимальный уровень разводимости, аналогичный уровню начала 1970-х гг., показатели брачности были более чем в 1,5 раза ниже уровня 1970 г., 
т.е. снижение уровня разводимости, характерное для середины - второй половины 1990-х гг., на наш взгляд, вовсе не свидетельствует об усилении в этот период устойчивости функционирования семьи.

Во-первых, это следствие значительного сокращения в связи со снижением официальной брачности числа молодых браков: в середине 1990-х гг. более трети разводов приходилось на браки продолжительностью до 5 лет. Во-вторых, это следствие широкого распространения фактических браков, имеющего место в 1990-е гг. [1]. С одной стороны, не оформленный юридически брак не требует и юридического оформления развода. А, с другой, фактическая брачность, охватывающая прежде всего повторную брачность, способствует и распространению фактической разводимости зарегистрированных первых браков - без юридического оформления факта развода. Существует также и такой нюанс: специалисты, регистрирующие демографические события, отмечали, что довольно распространенным явлением в 1990-е гг. стало пренебрежение населением, особенно мужчинами, фиксировать в органах ЗАГС разводы, совершенные в судебном порядке. Иными словами, часть даже юридически оформленных разводов не попадала в статистику разводимости - скорее всего, опять же в силу распространения фактической брачности в повторных браках. В-третьих, в условиях весьма низкого уровня жизни основной части населения и многомесячных задержек заработной платы, очень характерных для середины 1990-х гг., даже необходимость платить при разводе госпошлину могла быть фактором снижения официальной разводимости. И это тоже отнюдь не свидетельствует о повышении стабильности семейной жизни в 1990-е гг.

Распад семьи, развод затрагивает все стороны жизнедеятельности человека. Он влияет на его эмоциональное благополучие и состояние здоровья; порождает серьезные юридические проблемы; ставит разведенных, особенно женщин с детьми, в тяжелое экономическое положение; усложняет взаимоотношения с социальным окружением; обостряет проблемы, связанные с выполнением родительских обязанностей. Конечно, достаточно большая часть разведенных вновь создает семью. По данным за период с наличием детальной статистической информации по брачности и разводимости населения, ежегодно более четверти всех браков в Республике Коми совершается разведенными женщинами и мужчинами. Несмотря на первый неудачный опыт, семья представляет для них несомненную жизненную ценность. Однако исследователи отмечают, что повторные браки гораздо более неустойчивы, чем первые, особенно в первые годы своего существования. В таких браках удельный вес разводов с продолжительностью брака менее двух лет практически в два раза выше, чем аналогичная доля в первых браках. Лишь после 10 лет семейной жизни, когда бо́льшая часть неблагополучных повторных браков уже распалась, разводы в них становятся менее распространенными, чем в первых [22, с. 146-147].

Возраст разводящихся и увеличение стажа брака негативно влияют на психологическое самочувствие людей, затрудняя процесс адаптации после развода. Молодые люди быстрее восстанавливают эмоциональное равновесие, легче привыкают к новому стилю жизни. У них лучше перспективы для вступления в новый брак. В первой половине 1990-х годов, в условиях роста официальной разводимости, наблюдалось некоторое омоложение ее структуры. Во второй половине 1990-х - начале 2000-х гг. развод заметно «постарел». Если в середине 1990-х гг. молодежь до 30 лет традиционно превышала треть всех разводящихся, то в начале 2000-х гг. на возраст до 30 лет приходилось менее $30 \%$ всех разводов. У женщин, которые в возрастных группах до 25 лет характеризуются в полтора-два раза более высокой интенсивностью разводимости, чем мужчины, в возрастах до 30 лет в этот период совершалось менее трети разводов, в то время как в середине 1990-х удельный вес разводов до 30 лет у женщин превышал $40 \%$.

В первой половине 1990-х гг. возрастная медиана разводимости - возраст, к которому совершается половина всех разводов - и у женщин, и у мужчин Республики Коми приходилась на возрастную группу 30-34 лет. Однако мужская медиана разводимости уже в середине 1990-х гг. была довольно близка к верхней границе этой возрастной группы, а в 1996 г. она пересекла ее. У женщин медиана разводимости попадала на возрастную группу 30-34 лет буквально до конца 1990-х гг. Однако в начале XXI в. женская возрастная медиана разводимости в Республике Коми также пересекла 35-летний рубеж. К возрасту 40 лет в начале 2000-х гг. в республике регистрировалось около 60 \% разводов у мужчин и менее 65 \% - у женщин. В середине 1990 -х гг. эти цифры были выше более чем на $15 \%$.

Возрастная мода разводимости (возраст наибольшей интенсивности разводов) и у мужчин, и у женщин Республики Коми в начале 2000-х гг. по-прежнему приходилась на возраст 25-29 лет. Однако она также тяготела к переходу в следующую возрастную группу, пересекая время от времени 30-летний рубеж по отдельным категориям населения: чаще всего у мужчин. Так, в 2003 г. на возрастную группу 30-34 лет попала мода разводимости у всех мужчин республики и у сельских женщин. Однако уже в 2003 г. началось сокращение обязательного перечня показателей развития брачно-семейных отношений, разрабатываемых органами статистики: в указанном году в возрастной статистике разводимости населения Республики Коми появилась категория «возраст неизвестен», составившая довольно большой процент от числа разводов (у мужчин 18,5 \%, у женщин 11,6 \%), что существенно ограничивает достоверность результатов анализа возрастной структуры разводов. 
Постарел официальный развод за рассматриваемые полтора десятилетия не только по возрасту разводящихся, но и с точки зрения продолжительности брака. Как уже отмечалось, еще в середине 1990-х гг. около трети разводов совершалось в Коми в первое пятилетие брака. В начале 2000-х - лишь немногим более 20 \%. К этому времени период максимальной интенсивности разводимости устойчиво переместился из группы браков с продолжительностью 0-4 года в группу с продолжительностью 5-9 лет. А в 2001 г. количество расторгнутых браков с продолжительностью менее 5 лет оказалось меньше даже числа расторгнутых браков с продолжительностью 10-14 лет. Причины этого, думается, также следует искать прежде всего в снижении в 1990-е гг. уровня официальной брачности: в относительно малом количестве молодых браков по сравнению с числом браков большой продолжительности. Однако такое постарение структуры разводов на стыке столетий - как по продолжительности брака, так и по возрасту разводящихся - следует расценивать как не вполне благоприятную тенденцию с точки зрения вероятности повторного семейного опыта.

Несмотря на постарение структуры разводов, в начале 2000-х гг. по-прежнему весьма существенная их часть приходилась на семьи, в которых супруги относятся к наиболее репродуктивным возрастам. Однако утверждение, что это существенно влияет на уровень рождаемости [23, с. 47], думается, является не совсем верным. На наш взгляд, в условиях режима низкой рождаемости связи между разводимостью и рождаемостью почти нет. При невысоких репродуктивных ожиданиях, тяготеющих к двум детям, репродуктивная потребность женщины имеет возможность удовлетвориться и при благополучном течении ее семейной жизни, и при разводе с последующим заключением повторного брака, и при разводе без вторичного брака. А развод с последующим вторичным браком может даже увеличить число детей, рожденных женщиной, сверх первоначальных ее ожиданий: в новой семье репродуктивные установки могут возрасти вследствие стремления супругов иметь общего ребенка (детей). На число детей, рожденных женщиной к концу ее репродуктивного периода, может повлиять, скорее, длительное проживание в формальном браке без его расторжения, чем факт развода.

Тем не менее одна из наиболее значимых проблем развода связана с тем, что он затрагивает судьбы детей. Подавляющее большинство детей при разводе остается с матерью. Соответственно, с ростом уровня разводимости, наряду с ростом уровня внебрачной рождаемости, увеличивается удельный вес неполных семей, возглавляемых женщинами. Это одно из самых неблагоприятных для общества последствий высокого уровня дезорганизации брачно-семейных отношений. Помимо основной проблемы таких семей - экономической существует целый спектр трудноразрешимых вопросов, начиная с проблем социализации детей и кончая здоровьем, физическим и психическим, самих глав материнских семей.

В Республике Коми вплоть до 1988 г. более половины разводов происходили в бездетных семьях. В течение очень непродолжительного времени их удельный вес весьма заметно сократился: в середине 1990-х годов он едва превышал 30\%. При этом среди распавшихся семей с детьми росла доля семей с двумя и более детьми. В 1994 г. она превысила 40\% всех распавшихся семей с детьми, а в сельской местности составила почти половину. Иными словами, в конце 1980-х - первой половине 1990-х гг. прослеживалось не только уменьшение значимости детей как фактора, противодействующего официальному разводу, но и процесс исчезновения взаимосвязи вероятности развода и числа детей в семье.

Впоследствии, во второй половине 1990-х гг, доля бездетных семей в структуре официальной разводимости вновь несколько возросла - до 33-38 \%. При этом в структуре распавшихся семей с детьми сократилась доля семей с двумя и более детьми: в начале 2000-х гг. она была меньше трети всех распавшихся семей с детьми. Однако несомненно, что прежде всего это последствие очень низкого уровня рождаемости на всем протяжении 1990-х гг. Кроме того, подчеркнем, что все эти тенденции касаются лишь официальной разводимости. Без специальных исследований ничего нельзя сказать о том, как обстоит дело с наличием и количеством детей в семьях, распадающихся фактически - без юридического оформления. Поэтому необходимость направления усилий общества на то, чтобы родительство пережило брак, что взаимосвязано с общим повышением культуры развода, безусловно, очень актуально.

В последнее время, как уже отмечалось, о развитии брачно-семейных отношений исследователю доступна крайне скудная статистическая информация, дающая возможность проследить лишь общую динамику разводимости. После снижения второй половины 1990-х гг, с 2000 г. в Республике Коми, как и по стране в целом, еще с 1999 г. наблюдалось повышение уровня официальной разводимости. В 2001-2002 гг. максимальные уровни 1994-1995 гг. оказались не только достигнутыми, но и превышенными. В течение последующих трех лет (2002-2005 гг.) показатели разводимости вновь обнаружили тенденцию к снижению, сменившуюся затем четырехлетним ростом (2006-2009 гг.). В дальнейшем на протяжении пяти лет (2010-2014 гг.) для уровня разводимости населения республики была характерна колебательная динамика без видимого тренда. И лишь в последние четыре года (2015-2018 гг.) при колебательной динамике показателя в регионе вновь прослеживается убывающий тренд. В 2018 г. уровень разводимости населения Республики Коми соответствует уровню 2005 г. 
Таким образом, динамика разводимости населения находится в сильной зависимости от брачно-семейного законодательства, от отношения населения к разводам, а также от внешних обстоятельств, таких как война, изменение нравственно-психологического климата в обществе, социально-экономический кризис и пр. В Республике Коми, как и в целом по России, следует отдельно рассматривать несколько этапов разводимости. В советский период истории четко выделяются три этапа: этап законодательного разрушения брака, семьи и семейной собственности как социальных институтов (до середины 1930-х гг.); этап государственного восстановления института семьи и приспособления его к задачам тоталитарного государства (до середины 1960-х гг.); этап реформ, призванных придать либеральный характер правовому регулированию социалистических семейных отношений, испытывающих сильнейший кризис (со второй половины 1960-х гг.) [4, с. 78]. Постсоветский период ввиду своей незначительной продолжительности пока не позволяет выделять четкую периодизацию развития разводимости населения. Следует лишь отметить, что российский демографический кризис конца $\mathrm{XX}$ - начала XXI в. сопровождался критическими тенденциями и в развитии брачно-семейных отношений. При этом для разводимости, как и для других демографических процессов, характерной чертой стал колебательный характер динамики, даже некоторая цикличность развития: демографические события, отложенные населением на одном временном отрезке, концентрируются на другом. Однако лишь 1990-е и самое начало 2000-х гг. дают возможность полноценного анализа закономерностей разводимости населения: по типам населенных пунктов, по полу, по возрасту, по очередности и продолжительности брака, по наличию и количеству детей в семье. А после 2005 г. разрабатываемые органами статистики данные позволяют лишь фиксировать тенденции процесса в целом по всему населению региона.

\section{Литература}

1. Попова Л.А. Развитие брачно-семейных отношений в Республике Коми в 1920-1990-е годы // Историческая демография. 2018. № 2 (22). С. 38-44.

2. Декрет ВЦИК и СНК РСФСР от 19 декабря 1917 г. «О расторжении брака» // Собрание узаконений РСФСР. 1917. № 10. Ст. 152.

3. Кодекс законов об актах гражданского состояния, брачном, семейном и опекунском праве (принят на сессии ВЦИК 16.09.1918 г.) // Собрание узаконений РСФСР. 1918. № 76-77. Ст. 818.

4. Кощеев A.B. Расторжение брака по советскому законодательству // Вестник Вятского государственного университета. 2010. № 4-1. C. 75-79. DOI: 10.0000/cyberleninka.ru/article/n/rastorzhenie-braka-po-sovetskomu-zakonodatelstvu-1.

5. Синельников А.Б. Социально одобряемые причины развода в прошлом и настоящем // Социологические исследования, 1992. № 2. С. 27-37.

6. Постановление ВЦИК от 19.11.1926 г. «О введении в действие Кодекса законов о браке, семье и опеке РСФСР» // Собрание узаконений РСФСР. 1926. № 82. Ст. 612.

7. Постановление ЦИК СССР № 65 и СНК СССР № 1134 от 27.06 .1936 г. «О запрещении абортов, увеличении материальной помощи роженицам, установлении государственной помощи многосемейным, расширении сети родильных домов, детских яслей, и детских садов, усилении уголовного наказания за неплатеж алиментов и о некоторых изменениях в законодательстве о разводе» // Собрание законодательства СССР. 1936. № 34. Ст. 309.

8. Иванова Е.И. Трансформация брачности в России в XX веке: основные этапы // Демографическая модернизация, частная жизнь и идентичность в России: Матер. науч. конфер. (27-28 февраля 2002 г., г. Москва). URL: http://demoscope.ru/ weekly/knigi/konfer/konfer_010.html (дата обращения: 5.06.2020).

9. Указ Президиума Верховного Совета СССР от 8 июля 1944 г. «Об увеличении государственной помощи беременным женщинам, многодетным и одиноким матерям, усилении охраны материнства и детства, об установлении высшей степени отличия - звания «Мать-героиня» и учреждении ордена «Материнская слава» и медали «Медаль материнства» // Ведомости Верховного Совета СССР. 1944. № 37.

10. Демографический ежегодник Республики Коми. 2005. Сыктывкар, 2005.

11. Естественное движение населения Республики Коми за 2005 г. Экспресс-информация Комистата № 44-24-21/3 от 14.04.2006. Сыктывкар, 2006.

12. Демографический ежегодник Республики Коми. 2019. Сыктывкар, 2019.

13. Синельников А.Б. Брачность и рождаемость в СССР. М., 1989.

14. Демографический ежегодник России. Статистический сборник. М., 2000.

15. Естественное движение населения Российской Федерации за январь-сентябрь 2000-2001 гг. (статистический бюллетень). М., 2001.

16. Социально-экономические показатели регионов Северо-западного федерального округа в 1995-2002 гг. Статистический сборник. Сыктывкар, 2003.

17. Официальный сайт Росстата. URL: http://www.gks.ru/ (дата обращения: 5.06.2020).

18. Указ Президиума Верховного Совета СССР от 10 декабря 1965 г. № 4238-VI «О некоторых изменениях порядка рассмотрения в судах дел о расторжении брака» // Ведомости Верховного Совета СССР. 1965. № 49. Ст. 725.

19. Кодекс о браке и семье РСФСР от 30 июля 1969 г. // Ведомости Верховного Совета РСФСР. 1969. № 32. Ст. 1086.

20. Фотеева Е.В. Семья в современном буржуазном мире. М., 1988. 
21. Семейный кодекс Российской Федерации от 29 декабря 1995 г. № 223-Ф3 // Собрание законодательства Российской Федерации. 1996. № 1. С. 16.

22. Волков А.Г. Семья - объект демографии. М., 1986.

23. Сысенко В.A. Супружеские конфликты. М., 1989. 